\title{
Surveying Mutagenic and Anti-mutagenic Effects of Citrus Limon
}

\author{
Malihe Entezari', Ahmad Majd', Fathollah Falahian', Sedighe Mehrabian², \\ Mehrdad Hashemi ${ }^{3}$, Abolfazl Movafagh ${ }^{4}$
}

${ }^{1}$ Department of Biology, The Islamic Azad University, Tehran Research and Science Branch, Tehran, Iran. ${ }^{2}$ Department of Microbiology, The Faculty of Basic Science, University of Tarbiat Moalem, Tehran, Iran. ${ }^{3}$ Department of of Molecular Genetics, The Islamic Azad University, Tehran Research and Science Branch, Tehran, Iran. ${ }^{4}$ Department of Medical Genetics, Cancer Research Center, Shoha Hospital, School of Medicine, Shahid Beheshti University of Medical Science, Tehran, Iran.

\begin{abstract}
Background and objective: Cancer is one of the main causes of mortality in the world and countless mutagenic chemical compound kill millions of cancer patients every year. Scientists are searching for natural foodstuff to prevent cancer. The present paper examines anti-mutagenic and anti-carcinogenic effects of citrus lemon. Methodology: Human astrocytoma cancerous cell line was cultured in DMEM (Gibco) with FBS10\% (fetal bovine serum), L-glutamine, penicillin, and streptomycin at $37^{\circ} \mathrm{C}$ for two days. Then the samples were treated with citrus lemon juice and biotic potential of cells was examined through the MTT method. Anti-mutagenic and anti-carcinogenic effects of citrus lemon were studied through back mutation assessment standard method (Ames test). The test was done using Salmonella typhimurium strain (TA100) with the mutation in histidine operon that needs external histidine source. The strain creates the reverse colony in presence of carcinogenic agents (sodium azide). Findings: Based on the MTT method, human astrocytoma cancerous cell line demonstrated significant cellular death compared with the control groups $(\mathrm{p}<0.01)$. Ames test showed that the juice prevented back mutation and rate of inhibition, based on the anti-mutagenic effect, of half-ripen and ripen citrus lemon was $71.7 \%$ and $34.3 \%$ respectively. In addition, the anti-carcinogenic effect of half-ripen and ripen citrus lemon were $83.3 \%$ and 50\% respectively. Conclusion: Anti-mutagenic and anti-carcinogenic effects of citrus lemon were examined for the first time. The results showed that in this regard half-ripen citrus lemon was more effective than ripening citrus lemon.
\end{abstract}

Keywords: Anti-mutagenic- anti-carcinogenic- citrus lemons- human astrocytoma cancerous cell line

Asian Pac J Cancer Biol, 2 (1), 9-12

\section{Introduction}

Caused by several mutagenic and carcinogenic chemical compounds, cancer is one of the main causes of mortality in the world. According to the estimates, more than $75 \%$ of cancer cases are due to environmental agents [1-2]. Damages and genetic mutation in DNA sequence and mutation of genes and other changes in chromosomic structure are the main carcinogens [3]. Many mutagenic and carcinogenic elements induce their destructive effects by free radicals (e.g. reactive oxygen species (ROS)). Antioxidants can attenuate the destructive effects of ROS, which is known as the pathogen of cancer, cardiovascular disease, neurological
Submission Date: 11/12/2016 Acceptance Date: 01/25/2017

problems, and aging. Daily intake of antioxidants, as anti-carcinogen, improves immunity against free radicals [4-6]. Some vegetables and fruits are rich in antioxidants such as polyphenols, vitamin C \& E, beta-carotene, and lipoten, which are the main anti-carcinogenic edible compounds [7]. Citrus fruits are rich in antioxidants [8-9]. Ames test is one of the most common tests to measure anti-carcinogen and anti-mutagen effects. The test relies on using bacteria with specific mutation $[10,11]$ and the effects of different elements on cancerous cells cultured in vitro. For the first time, the present study attempts to examine the anti-carcinogen effect of half-ripen and ripen citrus lemon juice based on its effect on cancerous cells and Amex test.

\footnotetext{
Corresponding Author:

Dr. Abolfazl Movafagh

Department of Medical Genetics, Cancer Research Center, Shoha Hospital, School of Medicine, Shahid Beheshti University of Medical

Science, Tehran, Iran.

Email: movafagh.a@sbmu.ac.ir
} 


\section{Materials and Methods}

Cytotoxicity effect of citrus lemon juice on the cancerous cell line (in vitro) was examined through an experimental study and MTT assay. The results were computed based on stimulation index and analyzed though t-test.

Ames standard test was used to examine anti-carcinogen and anti-mutagen effects of the juice samples on salmonella Typhimurium mutated bacteria and the results were analyzed based on the colonial growth of the bacteria in an arbitrary condition using ANOVA.

Human astrocytoma cancerous cells (line 1321) were used. The cells were cultured in DMEN with 10-20\% FBS in an incubator $\left(37^{\circ} \mathrm{C}\right.$ and $\left.5 \% \mathrm{CO}_{2}\right)$. To carry out cell tests and incubation, after culturing adequate cells, the adhesive cells were extracted from flux foam by trypsin $(0.25 \%)$. Each experiment was replicated three times. Given that some of the cells were adhesive and needed to be in normal growth condition, all the experiments were done after $18 \mathrm{hrs}$ of incubation in cell culture plate wells (cells complete adhesion to plate).

The rate of living cells in cells suspension was obtained through the viability test. This technique enables us to control and adjust cells count and density in the culture; so that MTT mark on the cells distinguishes the living cells by purple crystals that are formed through oxidation of the dye by mitochondria dehydrogenation. The cell count is obtained based on the living cells percentage as follows:

Viability (biotic potential $)=($ number of living cells $/$ total number of culture cells) $* 100$

It took $18 \mathrm{hrs}$ for all cells to be completely attached to the plate and then different concentrations of juice $(25 \mu 1 / \mathrm{ml}$, $50 \mu \mathrm{l} / \mathrm{ml}, 100 \mu \mathrm{l} / \mathrm{ml}, 500 \mu \mathrm{l} / \mathrm{ml}$ and 0 as the control group) were added to the plates. Afterward, the plates were placed in an incubator $\left(37^{\circ} \mathrm{C}\right.$ and $\left.5 \% \mathrm{CO}_{2}\right)$.

Marking was done using the MTT method. The method is based on oxidation of dimethylthiazol diphenyl tetrazolium bromide so that purple unsolved formazan is formed by dehydrogenation of mitochondria enzyme on the living cells. MTT solution $(50 \mathrm{~m} / \mathrm{l})$ was obtained by solving 50mg MTT powder in $10 \mathrm{ml}$ of PBS ( 0.15 molar) and diluted before marking for ten times by PBS so that $0.5 \mathrm{mg} / \mathrm{ml}$ of MTT was obtained. It is notable that after preparation, the PBS solution was placed in the autoclave. Following incubation of cancerous cells with different concentration of the fruit juice for $48 \mathrm{hrs}$ $\left(37^{\circ} \mathrm{C}\right.$ and $\left.\mathrm{CO} 25 \%\right)$, the plate was marked by MTT $(0.5 \mathrm{mg} / \mathrm{ml})$. Afterward, the samples were kept in the incubator $\left(37^{\circ} \mathrm{C}\right)$ for $3-5 \mathrm{hrs}$ and then the overhead liquid was replaced by $200 \mu 1$ isopropanol solution (Germany, Merck) before placing the plate on the shaker for $10-15 \mathrm{~min}$. Then the samples were examined by microtiter plate reader (Elisa-reader, Organon-Teknika, Netherland) at 570nm. Induced toxicity was computed as follows:

$\%$ Cytotoxicity $=(1$-mean absorbance of toxicant $) *$ $100 /$ mean absorbance of negative control

$\%$ Viability $=100-\%$ Cytotoxicity

To have lower test error, MTT dye was added to a few empty wells cell and then the wells were washed and adsorption score of the empty wells was deducted from the total adsorption score.

Salmonella typhimurium (TA100) was used for Ames test. The histidine-dependent strain was supplied directly by Professor Ames. The experiments needed a fresh culture of bacteria and incubation time in the fresh overnight culture of the bacteria in nutrient broth must not exceed $16 \mathrm{hrs}$. The optimum concentration of the bacterial was $1-2 * 10^{9}$ cell $/ \mathrm{ml}$. After examining cytotoxicity effect of fruit juice on cancerous cells, Ames test was carried out by adding the juice to $0.5 \mathrm{ml}$ of fresh overnight culture of TA100 and $0.5 \mathrm{mmol}$ histidine and biotin each to a tube containing $10 \mathrm{ml}$ top agar $(50 \mathrm{gr} /$ lit agar $+50 \mathrm{gr} / \mathrm{lit} \mathrm{NaCl})$ and carcinogenic agent sodium azide $(1.5 \mu \mathrm{gr} / \mathrm{ml})$. The content of the pipe was expanded on the surface of glucose agar $(40 \%$ glucose at least) and placed in the incubator of $48 \mathrm{hrs}$ at $37^{\circ} \mathrm{C}$. Three replicates of each treatment were prepared and incubation, back colonies in the experiment, and control plates were counted. The results were compared after angular transfer using variance analysis.

There are several compounds that are inactive, in their stable form, in terms of mutagenic and carcinogenic effects; to have such effects, they need to be activated. That is, it is necessary to add sterile fruit juice to the micro chromosomic extract of mammals' liver cells (e.g. mouse). Therefore, hepatectomy was performed on 10 male mice after $24 \mathrm{hrs}$ fasting. Having no food stimulates and increases liver enzyme secretion. The livers were homogenized in potassium chloride $(0.15 \mathrm{~mol})$ and centrifuged for $10 \mathrm{~min}$ (9000rpm, $4^{\circ} \mathrm{C}$ ). The overhead liquid (S9 mixture) was removed and mixed by the required cofactors (NADP and phosphate glucose 6$) ; 0.5 \mathrm{ml}$ was added to Top agar mixture to examine anti-cancer effects.

After counting the colonies in anti-carcinogenic and anti-mutagenic tests, inhibition or antioxidant effect was obtained as follows [12].

$$
\text { Inhibition rate }=(1-\mathrm{T} / \mathrm{M}) * 100
$$

Where, T represents back colonies adjacent to the mutagenic element and the fruit juice in each petri dish and $\mathrm{M}$ represents back colonies in the Petri dishes of positive control (mutagenic agent).

\section{Findings}

Comparison of the results obtained from the MTT test on cancerous cells adjacent to different concentrations of fruit juice revealed loss of biotic potential of cancerous cells. There was a significant difference between the halfripen and ripen fruit juices in inhibiting the growth of cancerous cells $(\mathrm{p}<0.05)$; so that the former had the more inhibiting effect (Diagram 1).

Count of colonies adjacent to $25 \mu 1$ of the fruit juice (given the results of biotic potential test results) indicated that half-ripen and ripen fruit juices had significantly different effects in terms of anti-mutagenic effects on colony growth comparing with control samples (sodium azide and distilled water $)(\mathrm{p}<0.05)$. Ripen and half-ripen 


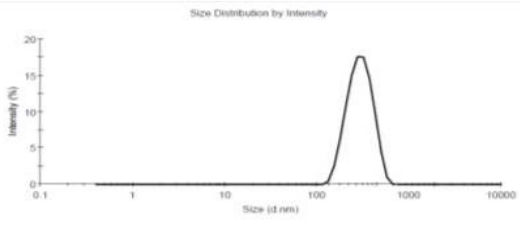

Diagram 1. Biotic Potential of Cancerous Cells after Treatment by the Ripen and Half-Ripen Fruit Juices

fruit juices had moderate (34.36\%) and strong (71.71\%) anti-mutagenic effects respectively. For instance, by adding S9 for metabolic activation of the juice, Ames test was replicated to examine the anti-cancer effect and, compared with the control (sodium azide and distilled water) the half-ripe fruit juice had higher anti-carcinogenic effects on colony growth $(\mathrm{p}<0.05)$.

Additionally, there was a significant difference between the effect of half-ripen and ripen fruit juices $(\mathrm{p}<0.05)$. Although, both were strong anti-cancer agents so that carcinogenic inhibition rate of the ripen and half-ripen fruit juices reached $50 \%$ and $83.33 \%$ respectively.

\section{Discussion}

Given that standard cancer treatment methods (surgery, chemotherapy, and radiotherapy) affect both the cancerous and healthy cells [13], many authors have tried to find better anti-cancer drugs in herbal medicines. These medicines only affect the cancerous cells and leave the normal cells intact [14]. The effects of different edible antioxidants on cancer and cardiovascular diseases have been proven so that they increase longevity up to $60 \%$ [15]. Laboratory surveys of poly-metoxilate flavonoids including tangertine showed that this compounds have antioxidant and anti-cancerous effects and protect neurons [16]. The effect of limonins (flavonoids) on cellular cycle was examined in 2001 and the results confirmed these compounds cause changes in cellular division or apoptosis so that cellular division happens at the G1 stage [17]. Another set of experiments in 2005 on nobiletin (a flavonoids found on citrus peels) supported anti-cancer, anti-virus, and anti-inflammation effects [18]. A study in 2006, based on MTT method, reported anti-cancer effects of citrus limonoids to extract on neuroblastoma cancerous cells (SH-SY5Y) and adenocarcinoma (Caco-2); the results showed the higher sensitivity of neuroblastoma [19]. Authors in [20] showed that inducing apoptosis is done by caspase. In [21-24] the four main systems that initiate apoptosis were listed including signal paths that induce cascade activation of caspase enzymes, cellular damages that increase penetrability of mitochondria membrane and activate caspases enzymes,
DNA damage that lead to augmentation of P53 protein and facilitates DNA repair by the said protein, and cellular membrane damage path that activates sphingomyelinase enzyme and generates ceramide factor out of lipid compounds of cell membrane.

Taking into account the sensitivity of neuroblastoma cancerous cells, growth inhibition effect of citrus lemon on human astrocytoma cancerous cells through the MTT method was supported. Anti-carcinogenetic effect of citrus fruit was introduced in 2002 by analyzing the chemical compounds of the fruits including vitamin $\mathrm{C}$, beta-carotene, flavonoid, limonoid, and acid folic [25]. Given the absence of any report about anti-mutagenic and anti-carcinogenic effects of half-ripen and ripen citrus lemon juice, anti-cancer effect of the fruit was examined using biotic potential and Ames tests and salmonella Typhimurium bacterium to determine anti-mutagenic and anti-carcinogenic effects. Half-ripen and ripen citrus lemon showed anti-mutagenic and anti-carcinogenic effects. According to Ames theory (1982), the agent is anti-carcinogenic and anti-mutagenic when the number of colonies on the positive control culture (with the mutagenic agent) is two times of the experiment sample. When the inhibition rate varies between 25 and $40 \%$, the anti-mutagenic effect is moderate, it is strong when the rate is more than $40 \%$, and it is negative when the rate is less than $25 \%$. This is also true in examining the anti-carcinogenic effect by adding S9 for metabolic activation $[10,11]$. These features were observed in citrus lemon juice samples. In vitro examinations on the effects of citrus lemon juice on cancerous cells culture showed that the juice repressed cancerous cells; moreover, the half-ripen citrus lemon was more effective than ripening citrus lemon.

Inhibition or antioxidant effects of the juices showed anti-carcinogenic and anti-mutagenic effects, while half-ripen citrus lemon was more effective than ripen ones. In 2000, [26] reported inducing of apoptosis in HL-60 cells by flavonoids of lemon. In 2007, [27] argued that the variation of $\mathrm{pH}$ in cancerous cells had anti-cancer effects. The higher effectiveness of half-ripen fruits might be due to the difference in flavonoids content or $\mathrm{pH}$ of the juice. As shown by anti-mutagenic test, citrus lemon juice induced anti-mutagenic effects. This paper used the fruit juice along with mouse liver extract (S9). Many anti-cancer agents are in inactive phase and cannot attach to DNA, while there is no electrophilic enzyme activity. Since the bacterium does not have this system, liver extract (S9) and cytochrome active system P-450/P-448 was used for activation [28]. As illustrated, the fruit juice along with S9 liver extract had anti-carcinogenic effects and half-ripen citrus lemon was more effective that ripen citrus lemon. This difference probably shows that a chemical compound in the juice needs P-4540/P-448 enzyme system for activation. 


\section{References}

1. Moller P, Wallin H, Knudsen LE. Oxidative stress associated with exercise, psychological stress and life-style factors. Chem Biol Interact. 1996;102(1):17-36.

2. Namiki M. Antioxidants/antimutagens in food. Critical reviews in food science and nutrition. 1990;29(4):273-300.

3. JM. M. Free radicals and prooxidants in health and nutrition. Food Technol 1994; . 106-10. p.

4. Clarkson PM, Thompson HS. Antioxidants: what role do they play in physical activity and health? The American journal of clinical nutrition. 2000;72(2 Suppl):637s-46s.

5. Fujiki H SM, Imai K, Nakachi K. Green tea: Cancer preventive beverage and /or drug. Cancer Lett, 2002; . 9-13 p.

6. Chen SC, Chung KT. Mutagenicity and antimutagenicity studies of tannic acid and its related compounds. Food and chemical toxicology : an international journal published for the British Industrial Biological Research Association. 2000;38(1):1-5.

7. Ghasemian A MS, Majd A. . Peel Extracts of two Iranian cultivars of Pomegranate(punica granatum) have antioxidant and antimutagenic activities. . Pak J Biol Sci 2006;; 7::1402405.

8. Jacob R HS, Manners G. The potential of Citrus Limnoids as anticancer agents. . perishables Handling Quarterly $2000 ; ; 102:: 6-8$

9. Mazaki M, Ishii T, Uyeta M. Mutagenicity of hydrolysates of citrus fruit juices. Mutation research. 1982;101(4):283-91.

10. Ames BN, McCann J, Yamasaki E. Methods for detecting carcinogens and mutagens with the Salmonella/mammalianmicrosome mutagenicity test. Mutation research. 1975;31(6):347-64.

11. Ames BN, Durston WE, Yamasaki E, Lee FD. Carcinogens are mutagens: a simple test system combining liver homogenates for activation and bacteria for detection. Proceedings of the National Academy of Sciences of the United States of America. 1973;70(8):2281-5.

12. Ong TM, Whong WZ, Stewart J, Brockman HE. Chlorophyllin: a potent antimutagen against environmental and dietary complex mixtures. Mutation research. 1986;173(2):111-5.

13. Chabner BA, Friedman MA. Progress against rare and notso-rare cancers. The New England journal of medicine. 1992;326(8):563-5.

14. Franks LM TN. Introduction to the cellular and molecular biology of cancer. New York: Oxford university press; 1997.

15. Sun J, Chu YF, Wu X, Liu RH. Antioxidant and antiproliferative activities of common fruits. Journal of agricultural and food chemistry. 2002;50(25):7449-54.

16. Bennett JP, Gomperts BD, Wollenweber E. Inhibitory effects of natural flavonoids on secretion from mast cells and neutrophils. Arzneimittel-Forschung. 1981;31(3):433-7.

17. Nijveldt RJ, van Nood E, van Hoorn DE, Boelens PG, van Norren K, van Leeuwen PA. Flavonoids: a review of probable mechanisms of action and potential applications. The American journal of clinical nutrition. 2001;74(4):418-25.

18. Li S, Yu H, Ho CT. Nobiletin: efficient and large quantity isolation from orange peel extract. Biomedical chromatography : BMC. 2006;20(1):133-8.

19. Poulose SM, Harris ED, Patil BS. Antiproliferative effects of citrus limonoids against human neuroblastoma and colonic adenocarcinoma cells. Nutrition and cancer. 2006;56(1):103-12.

20. Poulose SM HE, Patil BS. Citrus limonoids induce apoptosis in human neuroblastoma cells and have radical scavenging activity. Am Soci Nutr Sci 2005; 870-77. p.

21. Lynch DH, Ramsdell F, Alderson MR. Fas and FasL in the homeostatic regulation of immune responses. Immunology today. 1995;16(12):569-74.

22. Nozawa K, Kayagaki N, Tokano Y, Yagita H, Okumura K, Hasimoto H. Soluble Fas (APO-1, CD95) and soluble Fas ligand in rheumatic diseases. Arthritis and rheumatism. 1997;40(6):1126-9.

23. Gavrieli Y, Sherman Y, Ben-Sasson SA. Identification of programmed cell death in situ via specific labeling of nuclear DNA fragmentation. The Journal of cell biology. 1992;119(3):493-501.

24. Kerr JFR SJ, Harmon BV, Bishop CJ. Apoptosis. In: Potten CS (ed). Perspectives on mamalian cell death. Oxford: Oxford University Press; 1987:;93.

25. Silalahi J. Anticancer and health protective properties of citrus fruit components. Asia Pacific journal of clinical nutrition. 2002;11(1):79-84.

26. Ogata S, Miyake Y, Yamamoto K, Okumura K, Taguchi H. Apoptosis induced by the flavonoid from lemon fruit (Citrus limon BURM. f.) and its metabolites in HL-60 cells. Bioscience, biotechnology, and biochemistry. 2000;64(5):1075-8.

27. Gross L. Manipulating cellular $\mathrm{pH}$ suggests novel anticancer therapy. PLoS biology. 2007;5(1):e10.

28. Hakura A, Shimada H, Nakajima M, Sui H, Kitamoto S, Suzuki S, et al. Salmonella/human S9 mutagenicity test: a collaborative study with 58 compounds. Mutagenesis. 2005;20(3):217-28

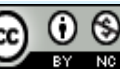

This work is licensed under a Creative Commons AttributionNon Commercial 4.0 International License. 